\title{
Revelation of ‘Hidden’ Balinese Geospatial Heritage on A Map
}

\author{
Dicky A.S. Soeria Atmadja, ${ }^{a}$ Ketut Wikantika, ${ }^{a}$ Agung Budi Harto, ${ }^{b}$ and Daffa Gifary M. Putra ${ }^{c}$ \\ ${ }^{a}$ Center for Remote Sensing, Institute of Technology Bandung, Bandung, West Java, Indonesia; ketut@gd.itb.ac.id, \\ mailtodicky@gmail.com \\ ${ }^{b}$ Remote Sensing and Geographic Information Sciences Research Group, Institute of Technology Bandung, Bandung, West Java, \\ Indonesia; abh.geodesi@gmail.com \\ ${ }^{c}$ Geodetic \& Geomatics Engineering Study Program, Institute of Technology Bandung, Bandung, West Java, Indonesia; \\ daffagifary@gmail.com
}

\begin{abstract}
Bali is not just about beautiful nature. It also has a unique and interesting cultural heritage, including 'hidden' geospatial heritage. Tri Hita Karana is a Hinduism concept of life consisting of human relation to God, to other humans and to the nature (Parahiyangan, Pawongan and Palemahan), Based on it, -in term of geospatial aspect- the Balinese derived its spatial orientation, spatial planning \& lay out, measurement as well as color and typography. Introducing these particular heritage would be a very interesting contribution to Bali tourism. As a respond to these issues, a question arise on how to reveal these unique and highly valuable geospatial heritage on a map which can be used to introduce and disseminate them to the tourists. Symbols (patterns \& colors), orientation, distance, scale, layout and toponimy have been well known as elements of a map. There is an chance to apply Balinese geospatial heritage in representing these map elements.
\end{abstract}

Keywords: Bali, Balinese Culture, Geospatial Heritage, Tourism

\section{Introduction}

Bali -'the Island of God'- is a province, lies in the middle-south of Indonesia. Located near to the equator, this $5,780 \mathrm{~km} 2$ island has tropical climate, similar to other regions in Indonesia. As a tropical island, Bali undoubtedly has many beautiful beaches and mountains which make it as one of the world best tourist destinations. In 2010 Bali received the Best Island award from Travel and Leisure for its attractive surroundings (mountain and coastal areas), diversity of tourist attractions, excellent international and local restaurants, and friendliness of local people. Bali stands as the second World's Best Island and first in Asia (http://www.travelandleisure.com/worlds-best/islands). According to BBC Travel (2011), Bali is one of the World's Best Islands, second after Santorini, Greece (http://www.bbc.com/travel/story/20111123-worlds-bestislands). These achievements are reflected on 2.88 million international tourists and 5 million domestic tourists visited Bali in 2012, as reported by Bali Tourism Office.

Behind its beautiful nature, Bali has a unique and rich culture, which was influenced by Indian (Hindu) culture beginning at the 1 st century. The culture is based on a Hinduism concept of Tri Hita Karana or three causes of welfare and prosperity. It consists of soul, power and physical elements, associated with Parahyangan or the relationship between god and human, Pawongan or interhuman relationship and Palemahan or the relationship between human and nature (Yasna et al, 2012). This concept is the fundamental of Balinese aspects of life, including their perspective and understanding of space.

Bali's record in tourism is exceptional. However, two big issues arise in this successful period.
1)There is a shift in Bali tourism trend recently. Despite the tourists visit to Bali increase by $22 \%$, hotel occupancy rates decrease by $8 \%$, but on the other side traditional cottages and houses occupancy rates in the villages increase by $4 \%$. Based on the University of Indonesia's report in 2016, tourists want to see and appreciate more about Balinese culture or cultural heritage, rather than only its beautiful nature.

2)Most of tourism activities in Bali are concentrated at the south of the province, near the capital city of Denpasar and Ngurah Rai International Airport, whereas the beauty of Bali is spread all over the province. According to Bali Tourism Office, there are still a lot of destinations -categorized as Emerging Tourism Objects and Destinations- which are only visited by small number of tourists.

Those unexplored destinations as well as the uniqueness and richness of Balinese culture are considered as 'hidden'. The Bali Tourism Office needs to take several steps to disseminate these informations. The aim is to increase tourist awareness that Bali is much bigger and richer than only several well-known natural tourist destinations. Therefore, contents and appropriate media forms which familiar to tourists need to be chosen, as it would be used as educational tool for them. In the context of cartography, it is a tourist map.

Obviously, the tourist map will not be a regular one which are often used. It will be a map that reveal Balinese culture and new emerging tourism destinations. The objective of this research is 'How to reveal and disseminate hidden Balinese unique culture and hidden tourism destinations through a unique tourist map designed based on Balinese cultural heritage,' This paper 
will discuss the process of designing the symbols, layout and other elements of the map.

\section{Methods}

Designing a map is to evoke in the minds of viewers an environmental image appropriate to the map's purpose. The two aspects of map design are to assign specific meaning to distinctive marks and arranging them in a total composition that will make the viewer see the result intended. Three important components of map design are color, pattern, and typography. (Robinson et al, 1995)

A thematic map -e.g. tourist map- is concerned with portraying the overall form of a given geographical distribution, from each part to the whole in a structural relationship. A tourist map should meet the tourist needs with accurate spatial relationship informations, specific informations needed, and ballanced amount of information. It should also bear in mind the kind of tourist it is developed for and where it will be used. (Foote and Crum, 1995).

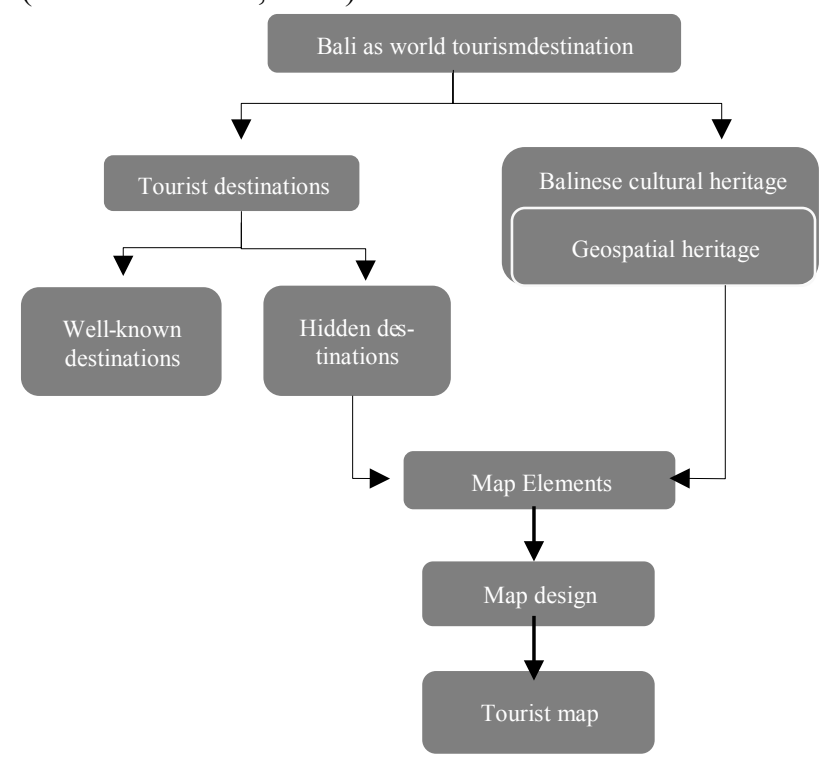

Fig 1. Working scheme of designing tourist map presenting hidden tourist destination and Balinese geospatial heritage

The design concept is to represent Balinese hidden tourism destination and Balinese cultural heritage, particularly geospatial heritage. These cultural heritage will be presented in each of map elements which are designed as derivation of cultural heritage entities in Bali. Map users are encouraged to recognize the meaning of characteristic contained in each element through infographics and descriptions regarding Balinese cultural heritage appeared on the rear side. On the other hand, the list of new emerging destinations is obtained from Bali Tourism Objects and Destinations 2009 book by Bali Tourism Office on Emerging Tourism Objects and Destination category. These 92 hid- den tourist destinations spread throughout the island.

In brief, the working scheme of designing a tourist map representing hidden tourist destinations and Balinese geospatial heritage is shown in Figure 1.

\subsection{Point Symbols Pattern}

According to the 92 hidden tourist destinations from Bali Tourism Office, they are classified into 10 classes, i.e. beach, temple, palace, cultural village, monument \& inscription, museum, water attraction, cave, hills \& rice terrace, and other attraction. Symbols pattern representing each destination class are derived from real object shape (see figure 2).
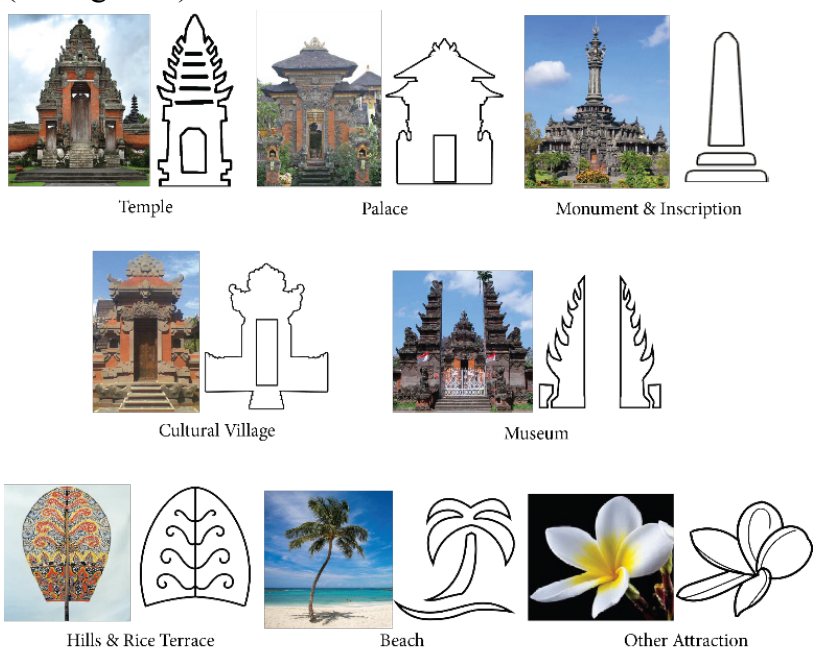

Hills \& Rice Terrace
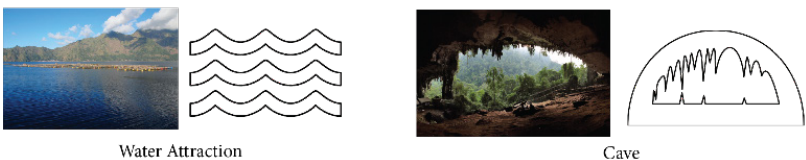

Fig 2. Symbol Pattern, some are derived directly from its original shape.

\subsection{Colors}

Balinese Hindu people believe that their Gods always keep the balance between Bhuana Agung or macrocosmos, meaning the universe and Bhuana Alit or microcosmos, meaning the human. To achieve the balance, the Gods guard the stability of 9 (nine) point of directions. In Bali, it is recognized as Dewata Nawa Sanga concept. Each di- rection has its own God and a signature color[3]. Figure 3 shows the Dewata Nawa Sanga concept.

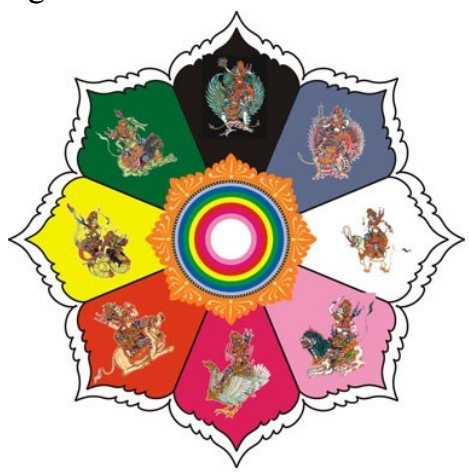

Fig 3. Dewata Nawa Sanga. (Source: Nitiasih 2010)

Each color of these 9 Gods has its own meaning. These colors are then adopted as symbol's color based on its meaning. Table 1 describes the color adoption. 


\begin{tabular}{|c|c|c|}
\hline $\begin{array}{l}\text { Colo } \\
\mathbf{r}\end{array}$ & Meaning & $\begin{array}{l}\text { Symbol } \\
\text { Adoption }\end{array}$ \\
\hline $\begin{array}{l}\text { Gree } \\
\text { n }\end{array}$ & $\begin{array}{l}\text { Unification of sunset \& } \\
\text { sea, balance, perfection }\end{array}$ & Beach \\
\hline $\begin{array}{l}\text { Blac } \\
\mathbf{k}\end{array}$ & Mountain, keeper & $\begin{array}{l}\text { Museum; } \\
\text { Monument } \quad \& \\
\text { Inscription }\end{array}$ \\
\hline Blue & $\begin{array}{l}\text { Unification of sun \& sea, } \\
\text { nature balance, freedom } \\
\text { of spirit }\end{array}$ & $\begin{array}{l}\text { Beach; Water } \\
\text { Attraction; sea; } \\
\text { river; lake }\end{array}$ \\
\hline $\begin{array}{l}\text { Whit } \\
\text { e }\end{array}$ & $\begin{array}{l}\text { Sun, unifier, source of } \\
\text { resurrection }\end{array}$ & Cultural Village \\
\hline Pink & $\begin{array}{l}\text { Unification of mountain } \\
\& \text { sun, sense killer }\end{array}$ & $\begin{array}{l}\text { Hills \& Rice } \\
\text { Terrace }\end{array}$ \\
\hline Red & Creator and power & Palace \\
\hline $\begin{array}{l}\text { Ora } \\
\text { nge }\end{array}$ & $\begin{array}{l}\text { Unification of mountain } \\
\& \text { sunset, repellent, fury }\end{array}$ & Cave \\
\hline $\begin{array}{l}\text { Yello } \\
\text { w }\end{array}$ & $\begin{array}{l}\text { Sunset, balance and } \\
\text { power keeper }\end{array}$ & - \\
\hline $\begin{array}{l}\text { Bru } \\
\text { mbu } \\
\text { n }\end{array}$ & Center, purity & Temple \\
\hline
\end{tabular}

Table 1. Dewata Nawa Sanga colors and color adoption for point symbols

\subsection{Scale}

Balinese use their own traditional system to measure short and long distances to build temple, house or village, planning a trip or other spatial activities. Sikut is their short measuring system using finger, hand, arm, elbow, foot. For longer distances, Panimpukan and Panelengan are used (see figure 4).
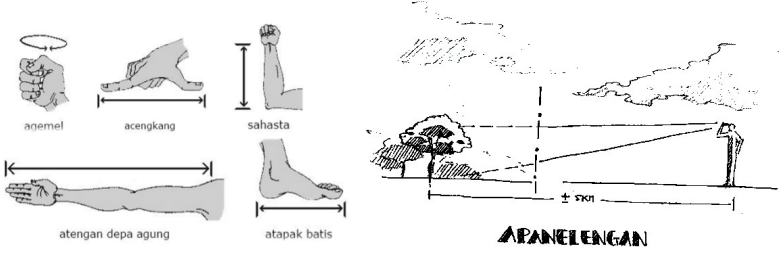

Fig 4. Sikut and Panelengan

According to Assessment of Architectural Perspective by I Ketut Adimarsa, a penelengan equals to approximate- ly $5 \mathrm{~km}$ vision. Since Bali is a large island, it is appropriate for a tourist map to use Panelengan as distance unit on the map's scalebar.

\subsection{Orientation}

A unique system found in Balinese traditional spatial orientation, which is still used today. Instead of NorthSouth-East-West, Balinese refer their spatial orientation to Kaja (to mountain), Kelod (to sea), Kangin (to sunrise) and Kauh (to sunset).

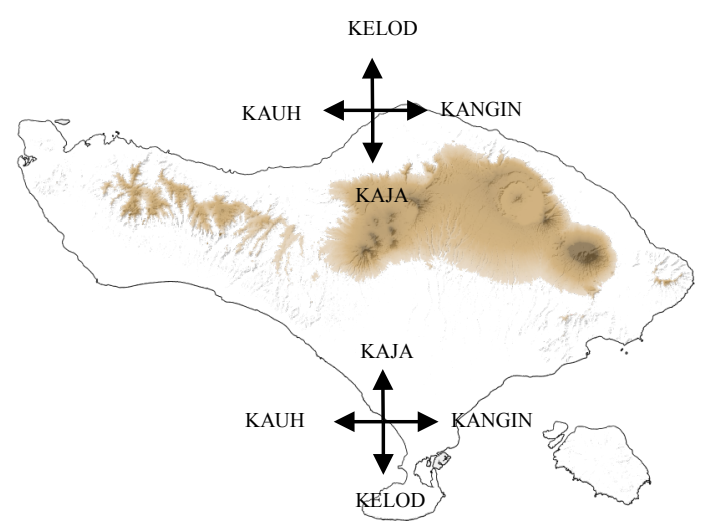

Fig 5. Different orientation on the northern and southern Bali.

The southern Balinese people call the north as 'kaja', south as 'kelod', east as 'kangin', and west as 'kauh' while the northern people call north as 'kelod' and south as 'kaja'; east and west remain the same (see figure 5). It is be- cause of their geographical location is oriented relatively to the mountain, which is located in the middle of the is- land stretched from west to east. Hence, the southern people, who has mountains on their north and Indian Ocean on their south, call north as 'kaja' and south as 'kelod' and vice versa for the northern people.

\subsection{Layout}

Balinese has a unique architectural layout for their traditional house, named Asta Kosala Kosali. The concept is based on 2 imaginary axis (as described in section 2.4); where kaja and kangin represent goodness, while kelod and kauh represent badness. Combining these 2 value axis system will form a unique space division named Sanga Mandala or 9 spatial section (Adhika, 1994).
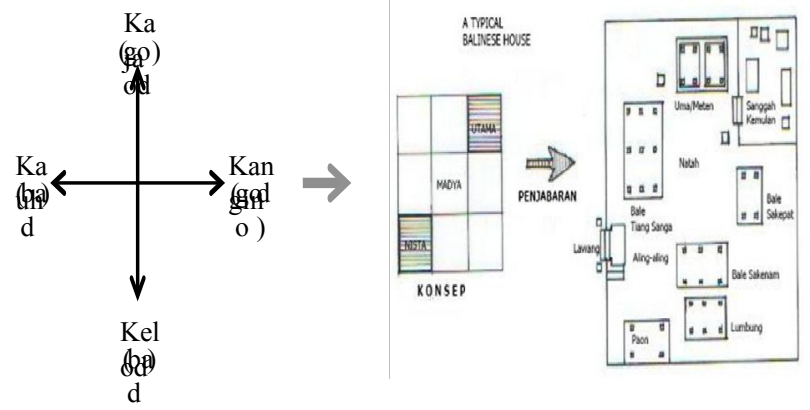

Fig 6. Asta Kosala Kosali, from 2 axis to 9 sections

This particular layout is then implemented in a traditional house layout shown in figure 7. 


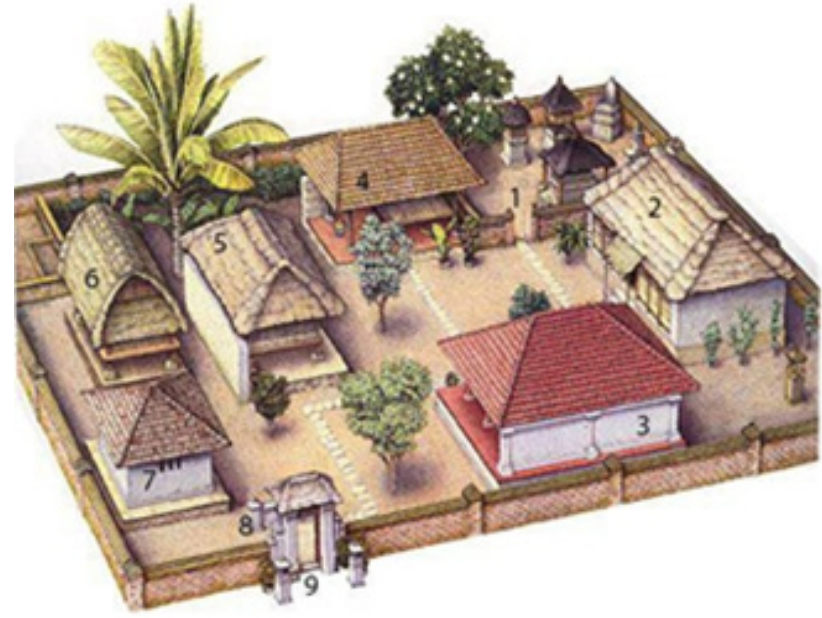

Fig 7. A Balinese traditional house layout.

Every section of Asta Kosala Kosali shown in figure 7 (represented by numbers) is described as follows:

3)Pamerajan (Sanggah Kemulan), place for family's religious activities, usually located at 'utama' section.

4)Umah Meten, place used by head of the family (parents) to have a rest. This section should be respectable.

5)Bale Sakepat, used as a bedroom for children or other junior family members.

6)Bale Tiang Sanga, usually for receiving guests

7)Bale Dangin, used to make artworks or weaving

8)Lumbung, place to store crops (rice, corn, etc)

9)Paon (kitchen), place for cooking

10) Aling-aling, a section used as an entryway diversion, so it is sideway rather than straightway. It is intended to obstruct views from outside to private sections inside.

11) Angkul-angkul, the entrance which has a shape of traditional gate.

This layout is adopted as the map layout, where map elements placed at the correlated section based on Sanga Mandala concept of spatial division. The Pamerajan section, brings out guidance of life to the family, is similar to the function of orientation sign as a guidance to map user. Bale Tiang Sanga, Bale Dangin and Natah (the central courtyard) are similar to the main section of a map as center of activity. Legend, map inset and map history are adopting the place of Paon and Lumbung as the compliment section, while map title is adopting the place of Angkul-angkul and Aling-aling as the main entrance to the map.

\subsection{Typography}

Balinese has its own alphabetical system called aksara bali, and also its own numerical system. It is used as an extra feature for the map's title and grid label.

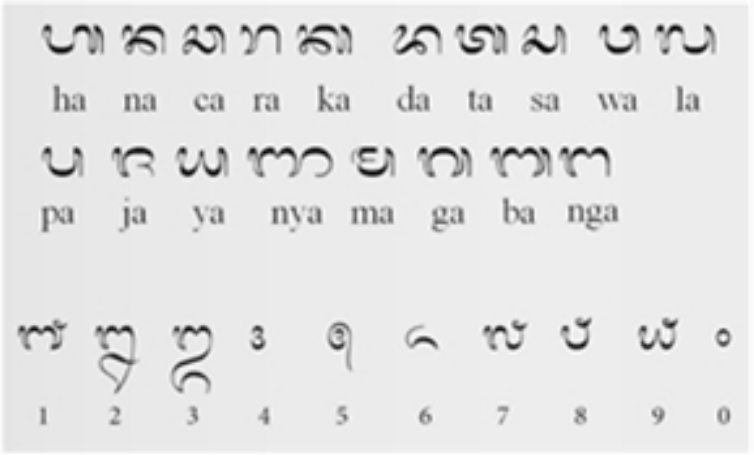

Fig 8. Aksara Bali

\section{Result}

shape and color of these symbols are then used to encourage tourist's curiosity on Balinese culture

\subsection{Point Symbols}

A set of qualitative pictorial symbol is resulted. These pictorial symbols are used to relieve users in associating particular symbol to its original object. The symbol's color adopts the Dewata Nawa Sanga concept based on its colors definition. Table 2 shows the list of point symbols.

\begin{tabular}{|c|c|c|c|}
\hline Symbol & Classification & Dimension (mm) & R-G-B \\
\hline ต & Beach & $5 \times 5$ & $\begin{array}{c}0-127-0 ; \\
0-127-255\end{array}$ \\
\hline & Temple & $5 \times 4$ & $\begin{array}{l}255-255- \\
0 ; \\
255-0-0 \\
255-255- \\
255 \\
\quad 0-0-0\end{array}$ \\
\hline & Palace & $5 \times 4$ & $255-0-0$ \\
\hline & Cultural Village & $5 \times 5$ & $\begin{array}{l}255-255- \\
255\end{array}$ \\
\hline & $\begin{array}{l}\text { Monument \& } \\
\text { Inscription }\end{array}$ & $5 \times 4$ & $0-0-0$ \\
\hline$\$ 4$ & Museum & $5 \times 5$ & $0-0-0$ \\
\hline$\approx$ & Water Attraction & $5 \times 5$ & $0-0-255$ \\
\hline & Cave & $4 \times 5$ & $255-127-0$ \\
\hline 3) & Hills \& Rice Terrace & $4 \times 5$ & $\begin{array}{l}255-127- \\
127\end{array}$ \\
\hline & Other Attraction & $5 \times 5$ & \\
\hline
\end{tabular}

Table 2. Result of symbol design 


\subsection{Orientation}

The map use 2 (two) kinds of orientation sign that represents Balinese term of orientation and direction as seen in figure 9.
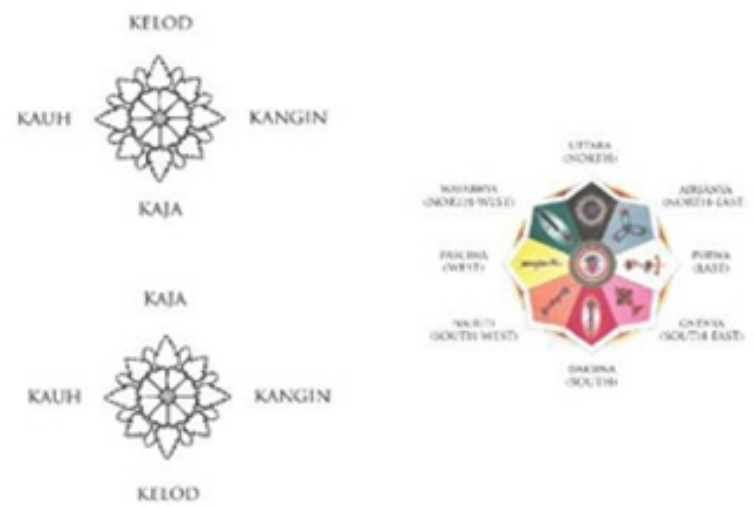

Fig 9. Balinese traditional orientation indicator (left); and northsouth direction indocator (right)

\subsection{Scale Indicator}

The map uses a graphics scale/ scalebar as seen in figure 10 , to relieve the user. There are 2 (two) kind of distance units on the scalebar, kilometers, and panelengan, which has been converted to metric units.

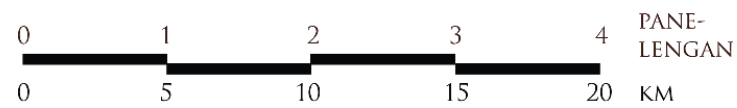

Fig 10. Scalebar with 2 kind of distance units

\subsection{Typography}

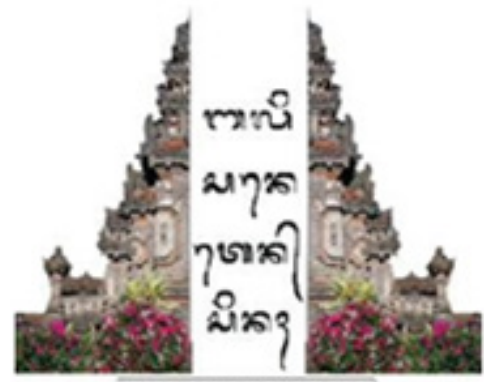

THE HIDDEN $3 A L L$

GALI SANE TEN SINAH.

Fig 11. Map title in Aksara Bali.

'The Hidden Bali' is the title of this map. Similar to other elements, to increase tourist awarenes to Bali cultural heritage, the title and coordinate number on the gridline are translitterated into Aksara Bali, the Balinese traditional alphabet. Coordinate numbers on the map's grid are also translitterated as well. Figure 11 shows the map title in Aksara Bali, while figure 12 shows the coordinate number.

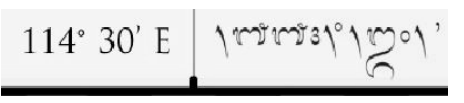

Fig 12. Coordinate number in Aksara Bali

\subsection{Map Layout}

The map layout is adapted from Balinese traditional architectural layout, Asta Kosala Kosali with Sanga Mandala spatial section. Figure 13 below is the result of map layout design.

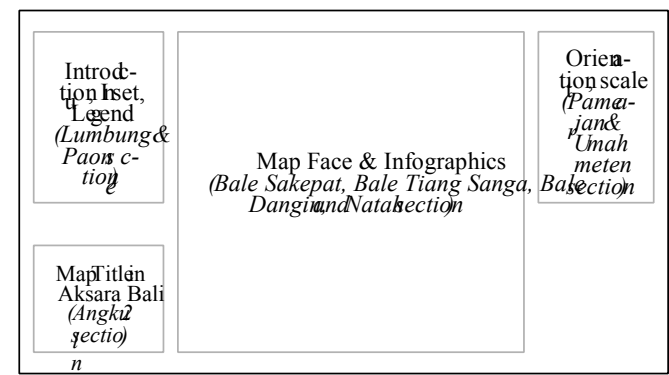

Fig 13. Map layout

\section{6 'The Hidden Bali' Map}
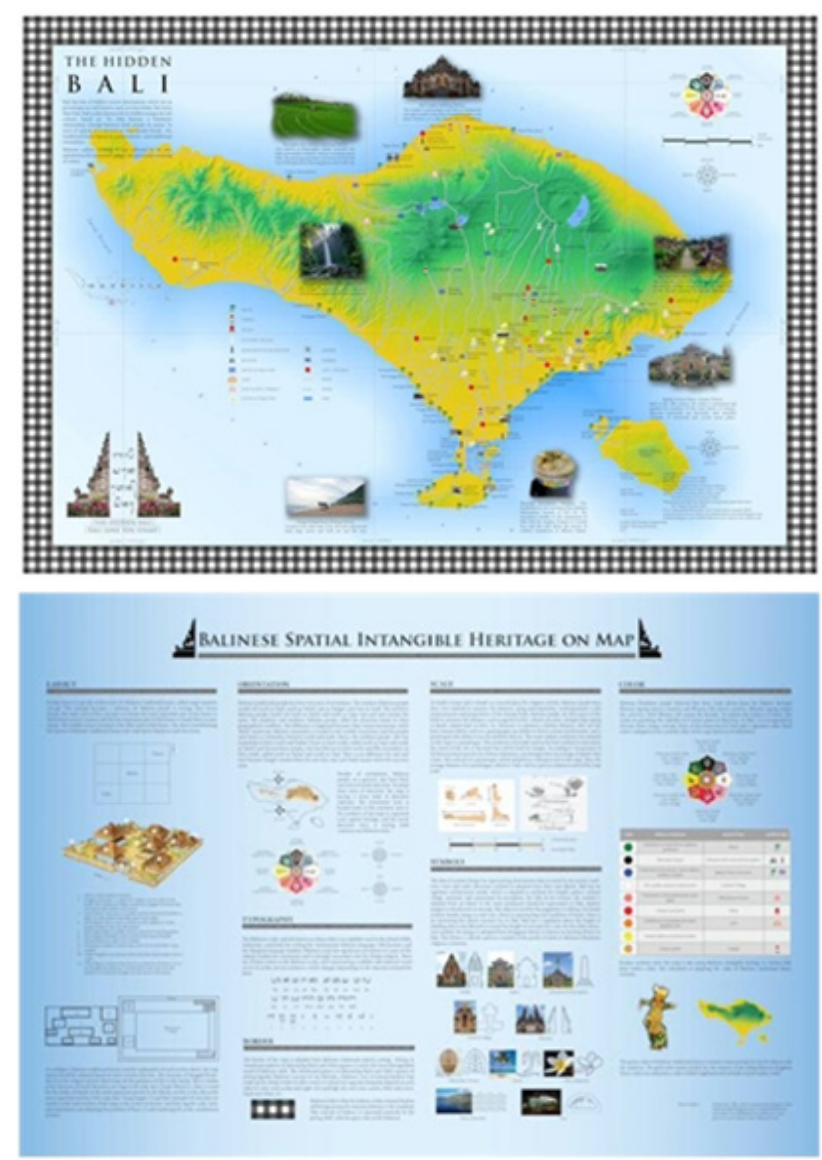

Fig 14. The map and its infographic side revealing Balinese 'hidden' geospatial heritage.

Figure 14 shows the tourist map and its infographic side containing informations regarding Balinese cultural heritage related to spatial aspects of the map's elements.

\section{Conclusion}

The geospatial heritage in Balinese culture are very interesting and challenging to be associated to common tourist map, particularly to each of its elements. Combining Balinese geospatial heritage and correlated 
map elements in designing tourist map could result a unique map which reveals Balinese culture. This map could also be used as a tool to endorse tourist to learn more about hidden Balinese culture and hidden Bali tourist destinations.

\section{References}

Dent, Borden D., (1999). Cartography: Thematic Map Design. 5th ed. WCB/McGraw Hill, Toronto

Dwijendra, N.K.Acwin. (2003). Perumahan dan Permukiman Tradisional Bali. Jurnal Permukiman "Natah" 1,1 Foote,

Keneth E., Crum, S. (1995), Cartographic Communication. University of Texas at Austin.

Nitiasih, P.K. (2010). Konsep Warna Dalam Dewata Nawa Sanga. Singaraja: Universitas Negeri Ganesha Singaraja.

Parwata, I Wayan (2009). Humanisasi Kearifan \& Harmoni Ruang Masyarakat Bali. Denpasar: Yayasan Tri Hita Karana Bali.

Robinson, Arthur H., Morrison, Joel L., Muehrcke, Phillip L., (1995), Elements of Cartography, 6th ed. John Wiley \& Sons, Canada

Wijaya, Made. (2003). Architecture of Bali: A Source Book of Traditional and Modern Forms. Thames \& Hudson Ltd. Yasna, Oka

I.G.N., Yoga, I.G.A., Widnyana, I.R., Adhi Tama, I.G.P., Putra, A.H. (2012). Tri Hita Karana. 